Primljen / Received: 15.9.2016. Ispravljen / Corrected: 24.3.2017.

Prihvaćen / Accepted: 18.4.2017. Dostupno online / Available online: 10.12.2017.

\section{Financial and socioeconomic analysis of waste management projects}

AutHorS:

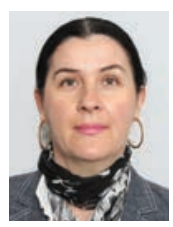

${ }^{1}$ Prof. Jasmina Ćetković, PhD in Economics jasmina@ac.me

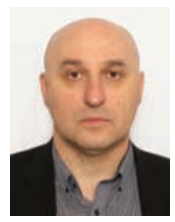

${ }^{1}$ Prof. Slobodan Lakić, PhD in Economics sasalakic@mail.com

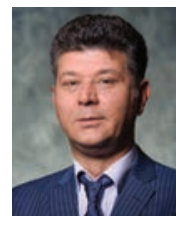

${ }^{2}$ Prof. Miloš Knežević, PhD. CE milosknezevic@hotmail.com

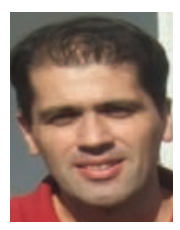

${ }^{3}$ Predrag Bogdanović, MsC. CE pedjabo1@gmail.com

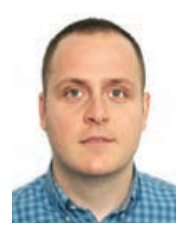

${ }^{4}$ Miloš Žarković, MSc in Economics milos.zarkovic87@gmail.com

${ }^{1}$ University of Montenegro, Faculty of Economics

${ }^{2}$ University of Montenegro, Faculty of Civil Engineering

Institute of Transportation, Serbia

${ }^{4}$ Erste Bank AD Podgorica, Montenegro
Professional paper Jasmina Ćetković, Slobodan Lakić, Miloš Knežević, Predrag Bogdanović, Miloš Žarković

Financial and socioeconomic analysis of waste management projects

A simulation of a financial and socio-economic analysis of a regional landfill construction project is conducted in the paper on a hypothetical example. The analysis showed that certain investment projects, particularly in developing countries, have a low or negative rate of financial profitability, due to the need to define a socioeconomically acceptable price. The final decision on the implementation of these projects is taken after conducting an appropriate socioeconomic analysis. Projects that are technically feasible and financially sustainable, but not commercially profitable, are suitable for public funding.

Key words:

project feasibility analysis, financial analysis, socioeconomic analysis, waste management sector

Stručni rad

Jasmina Ćetković, Slobodan Lakić, Miloš Knežević, Predrag Bogdanović, Miloš Žarković

Financijska i socioekonomska analiza projekata gospodarenja otpadom

U radu je provedena simulacija financijske i socioekonomske analize na hipotetskom primjeru projekta izgradnje regionalnog odlagališta. Analiza je pokazala da određeni investicijski projekti, posebno u zemljama u razvoju, zbog definiranja socioekonomski prihvatljivih cijena, imaju nisku ili negativnu stopu financijske rentabilnosti, pa se konačna odluka o realizaciji tih projekata donosi nakon provođenja socioekonomske analize. Projekti koje je moguće izvesti, financijsko održivi, ali ne i komercijalno isplativi, pogodni su za javno financiranje.

Ključne riječi:

analiza opravdanosti projekata, financijska analiza, socioekonomska analiza, gospodarenje otpadom

Fachbericht

Jasmina Ćetković, Slobodan Lakić, Miloš Knežević, Predrag Bogdanović, Miloš Žarković

Finanzielle und sozioökonomische Auswertung von großen Investitionsprojekten

In der Arbeit wurde eine Simulation einer finanziellen und sozioökonomischen Auswertung am Beispiel der Errichtung einer regionalen Deponie durchgeführt. Die Auswertung hat gezeigt, dass bestimmte Investitionsprojekte, insbesondere in den Entwicklungsländern, infolge von sozioökonomisch akzeptablen Preisen, eine niedrige oder negative Rentabilitätsrate besitzen, sodass der endgültige Beschluss über die Umsetzung dieser Projekte erst nach der Vornahme der sozioökonomischen Auswertung gefasst wird. Projekte, die umsetzbar und finanziell nachhaltig, kommerziell aber nicht rentabel sind, eignen sich für die Finanzierung aus öffentlichen Mitteln.

Schlüsselwörter:

Wirtschaftlichkeitsstudie, finanzielle Auswertung, sozioökonomische Auswertung, Abfallbewirtschaftungssektor 


\section{Introduction}

There are some differences between the criteria for making investment decisions, and the methods for assessing effects of such investments. Criteria for investment decisions are in fact the requirements for achieving the objectives that the decision maker wishes to achieve by the investment. They determine the character of the effects by which contribution of the investment is measured. Various methods are used for the calculation of the investment effects.

According to traditional analysis of financial feasibility of projects, the cash flows of an investment project is measured through the rate of return as elimination criterion [1], without considering the costs and benefits that the project would bring to the society as a whole. This analysis is used as a tool to test two specific factors that are relevant for assessing justification of investments such as the expected return on assets and the expected risk [2]. It can be used as adequate assessment of the feasibility of commercial projects, but is not suitable for investment projects of a public nature in which the net effects of the project are relevant for the society as a whole. In these projects, significant project effects (such as environmental, social, health, transport, etc.) are undisputed. Although they do not always have an appropriate market value, they significantly contribute to the achievement of project objectives. Socio-economic goals have become key requirements in many projects supported by international financial institutions and EU funds. Some of them often represent a legal obligation while others are important in order to achieve a social purpose. In these cases, the assessment of the project's social dimension, and the projection of socio-economic impacts of the project, are considered necessary.

The difference between the financial and socio-economic cost-benefit analysis of projects is due to the fact that in business practice, especially in less developed countries, there is a discrepancy between the freely formed market prices and factual prices, or in the disparity of costs and benefits from the perspective of the society. This is due to the economic policy measures of the state (subsidies policy, selective tax policy, etc.), market disruptions (deviation of official foreign-currency exchange rates from market regulated rates, high inflation unevenly distributed by sector), etc.

\section{Literature review}

In order to assess the profitability of investments, companies develop and analyse relevant cash flows and assess eligibility of projects. To this end, a number of capital budgeting techniques have been developed. Preferred approaches integrate time value, risk, and return of funds' procedures. In addition, there are differences between the capital budgeting in safe conditions compared to budgeting in unsafe circumstances [3]. The net present value (NPV) and internal rate of return (IRR) are the generally preferred techniques of capital budgeting. Since the NPV enables explicit consideration of the time value of money, it is considered to be a sophisticated capital budgeting technique.
In addition, the IRR is the most commonly used sophisticated technique [3].

Graham and Harvey's research from the late 20th century, which involved participation of 392 CFOs, showed that about $75 \%$ of CFOs always or almost always use IRR and NPV techniques [4]. At that, big companies tend to prefer present value techniques (more than as was revealed in previous research). Small companies (which are less inclined to take part in risky projects) more commonly use the refund period criterion. Therefore, the authors suggest that there is a link between the size of the company and corporate finance practice. However, the study did not show major differences in the use of these techniques between the growing and non-growing companies [4].

Danielson and Scott's study found that, unlike large firms that rely on discounted cash flow analysis, small firms (with less than 250 employees) assess projects based on less sophisticated tools (such as the period of recovery, the owner's feeling, etc.) [5], which is partly due to their inherent problems (liquidity issues, challenges relating to adequate cash flow evaluation, etc.).

However, previous studies, mostly based on large companies, indicate that the primary method of assessment was IRR. A survey conducted in the late 1980s shows that out of 108 American companies involved in the study, less than $10 \%$ of companies use NPV as the main method of assessment, while more than 50 $\%$ primarily use IRR [6]. The survey conducted in the mid-1990s showed that $65 \%$ of companies use IRR as the basic technique [7]. The research conducted in the same time span revealed that out of 288 companies (Fortune 500), $86 \%$ use some of the discounted cash flow techniques [8]. A decade later, a study presented in [9] showed that 73 out of 74 companies (Fortune 100) used discounting techniques. Similar results were shown by the study done in the mid-1990s on a sample of 84 companies (Fortune 500 and Forbes 200 best small companies) [10].

Thus, studies have shown that the NPV and IRR are the usual techniques of capital budgeting. However, the determination of financial NPV (FNPV) and financial IRR (FIRR) does not suffice for assessing justification of projects of general public interest, which are mostly of public nature in developing countries. For a final decision on such projects it is necessary to determine the indicators of economic NPV (ENPV) and economic IRR (EIRR) relevant for the assessment of these projects.

A topical segment of these types of projects are environmental projects and, within them, the waste management projects, which are presently of particular interest to developing countries. Since the 1990s, waste management has become an increasingly pertinent issue, and has thus been brought up to the level of a comprehensive approach, which has led to a change in traditional ways of waste management in developing countries. Due to limited resources, developing countries learn from developed countries about how to improve their Municipal Solid Waste Management (MSWM) practices. The transfer of such experience is hindered by the differences in regulations and allocation of resources, as well as by social, economic, demographic and technological conditions [11]. Over time, the MSWM has evolved into an approach focusing on various aspects [12], such as public 
health, engineering, planning [13], economic issues [14, 15], etc. As a comprehensive, systematic approach covering the process from waste generation to its final disposal, the MSWM has become an Integrated Waste Management approach equally recommended for developed and developing countries [16-18].

The biggest challenge facing local authorities of developing countries is to achieve maximum results with limited budget and the lack of relevant analyses on the cost and effectiveness of waste management projects [19]. Specific tools for estimating waste management costs enable assessment of resource requirements, with all the risks engendered by such assessment [20]. Improving quality of this assessment obviously enhances decision-making quality and rational management of available funding [19]. Due to absence of real-time cost calculations, the budget planning in this sector often relies on budget projections from previous periods $[21,22]$. Literature primarily presents quantitative approaches to planning costs developed through programming and optimization techniques, statistical methods, and cost-benefit analysis [23-25], as well as qualitative approaches to the cost analysis of certain activities within the waste management process, such as waste reduction activities, waste collection and disposal activities [26-28], waste sector privatization activities [29], etc. The existing methods for cost estimation (UCM, benchmarking, and cost modelling) show certain deficiencies if applied unvaryingly in different conditions. A large number of stakeholders involved in this process hinder objective assessment of costs. An integrated approach to the assessment of costs has been given an increasing significance in recent years. This approach combines the existing assessment methods in order to improve the cost planning process in the field of waste management [30].

\section{Analysis and results}

The main objective of our analysis is to show that the socioeconomic analysis is a basis for justification of projects where socio-economic effects are more important than financial effects. As a rule, these are the projects suitable for public funding, and this analysis is generally used as an instrument of their prioritization.

The following two research hypotheses were derived from the basic goal of this analysis:

$\mathrm{H} 1$ : Modern practice of investing is partly characterized by the projects for which there are no conventional markets suitable for profit making. In order to optimize the decision-making process at all levels, there is an undisputable need to consider significant impacts (environmental, social, health, etc.) these projects have on overall development of the community and the quality of life of its residents.

$\mathrm{H}$ 2: In developing countries, the investments in environmental protection, such as those made in the waste management sector, are mostly public sector investments. Here, positive financial results can not be expected as the prices of services have to acceptable from the socioeconomical standpoint (i.e., they should normally be lower compared to commercial rates).
Justification of these projects must be made through the prism of wider socio-economic effects, which have preference over purely financial effects.

The conduct of a financial and socio-economic feasibility analysis is presented below using a hypothetical example of construction of a regional landfill for municipal (non-hazardous) waste.

\subsection{Methodological framework of analysis}

Simulation of financial and socio-economic feasibility analysis, using a hypothetical example of a regional landfill for municipal (non-hazardous) waste, was done in accordance with the current EU methodology [31], and in compliance with European legislation in the waste management sector.

The analysis started with predefined general objectives of the investment, and with definition of certain key assumptions that allowed a more realistic analysis. The results of the analyses are reported in the form of a budget of key indicators for evaluation of financial and socio-economic feasibility of the project.

The financial analysis of the project included project assessment from the investor's perspective, testing financial sustainability of the project, and analysis of the project's sensitivity to the change of basic assumptions [32]. During analysis of financial sustainability of the regional landfill project, a financial model was used to predict financial performance and development of rates for waste collection and disposal at the landfill site. The analysis was based on the "incremental method" allowing comparison of "the scenario with the project" and "the scenario without the project", starting from the fact that previous analyses showed that "the scenario without the project" is worse than "the scenario with the project" due to ecological unacceptability.

The socio-economic analysis of the project involves assessment of its net contribution to the overall socio-economic wellbeing of the region and/or country. This analysis started from the indisputable fact that the observed market prices of the input and output values often fail to reflect their full social value. Certain projects often exhibit influences that are not expressed through direct market values, and they have to be monetized through various evaluation techniques depending on the nature of the effect. Many methods for estimating the socio-economic costs and benefits of the project can be used in the project feasibility analysis. The rule respected during this analysis was that the project expenditures are analysed through their opportunity costs, while gains (effects) of the project are measured by the willingness of the society to pay (a modern systemic approach) in order to achieve a given effect.

\subsection{Estimation of economic costs and benefits}

An estimate of investment and total operating costs is made in the part of the analysis focusing on estimation of economic costs. Total investment costs are estimated at $€ 8,686,538$. This amount includes the costs of education of landfill employees, which is estimated at $€ 100,000$. 
Table 1. Projection of workforce costs (in EUR)

\begin{tabular}{|c|c|c|c|c|c|c|c|c|c|}
\hline \multirow{2}{*}{ Position } & \multirow{2}{*}{$\begin{array}{l}\text { Number of } \\
\text { employees }\end{array}$} & \multirow{2}{*}{$\begin{array}{c}\text { Gross } \\
\text { salary }\end{array}$} & \multicolumn{7}{|c|}{ Year } \\
\hline & & & & 2021 & 2026 & 2031 & 2036 & 2041 & 2045 \\
\hline CEO & 1 & 1.400 & 17.136 & 19.287 & 22.359 & 25.920 & 30.048 & 34.834 & 39.206 \\
\hline Chief accountant & 1 & 1.200 & 14.688 & 16.531 & 19.165 & 22.217 & 25.755 & 29.858 & 33.605 \\
\hline Business secretary & 1 & 900 & 11.016 & 12.399 & 14.373 & 16.663 & 19.317 & 22.393 & 25.204 \\
\hline Facility manager & 1 & 1.200 & 14.688 & 16.531 & 19.165 & 22.217 & 25.755 & 29.858 & 33.605 \\
\hline Water facility operator & 1 & 1.000 & 12.240 & 13.776 & 15.970 & 18.514 & 21.463 & 24.881 & 28.004 \\
\hline Mobile equipment operator & 3 & 1.000 & 36.720 & 41.329 & 47.911 & 55.542 & 64.389 & 74.644 & 84.013 \\
\hline Laboratory technician & 1 & 900 & 11.016 & 12.399 & 14.373 & 16.663 & 19.317 & 22.393 & 25.204 \\
\hline Skilled worker & 1 & 900 & 11.016 & 12.399 & 14.373 & 16.663 & 19.317 & 22.393 & 25.204 \\
\hline Administrator & 1 & 900 & 11.016 & 12.399 & 14.373 & 16.663 & 19.317 & 22.393 & 25.204 \\
\hline Unskilled workers & 2 & 900 & 22.032 & 24.797 & 28.747 & 33.325 & 38.633 & 44.787 & 50.408 \\
\hline Cleaner & 1 & 700 & 8.568 & 9.643 & 11.179 & 12.960 & 15.024 & 17.417 & 19.603 \\
\hline Security & 3 & 800 & 29.376 & 33.063 & 38.329 & 44.434 & 51.511 & 59.715 & 67.210 \\
\hline Drivers & 8 & 900 & 88.128 & 99.189 & 114.987 & 133.302 & 154.533 & 179.146 & 201.630 \\
\hline Employees - total & 25 & & 287.640 & 323.741 & 375.305 & 435.081 & 504.378 & 584.713 & 658.100 \\
\hline
\end{tabular}

The workforce costs are calculated based on the staff number required and typical earnings for different categories of employees (including various insurances, taxes and contributions), increased by the predicted growth rate, as shown in Table 1.

General administrative costs are calculated as a percentage of the workforce costs and amount to $10 \%$ of the cost of workforce employed at the landfill. Fuel costs are calculated on the basis of the established annual consumption of 77,376 litres and a unit price of $€ 1.3$ per litre. Electricity costs are determined on the basis of a variable component (depending on the amount of disposed waste - $20 \mathrm{KWh}$ per ton of waste and a unit price of $0.07 € / K W h$ ) and a fixed component (in the amount of $€ 19,250$ per year, 275,000 KWh). Water costs are calculated on the basis of the established annual consumption of $936 \mathrm{~m}^{3}$ and a unit price of $€ 0.85$. Annual chemicals costs are assessed at $€ 21,000$, while the costs of monitoring, rehabilitation and insurance are estimated at $€ 60,000$, $€ 450,000$, and $€ 102,000$, respectively. The annual maintenance costs for all facilities are calculated based on a certain percentage of investment costs, and they are estimated at $5 \%$ for mobile equipment, $3 \%$ for machinery and electrical equipment, and $1 \%$ for the landfill and construction work. The costs of closing down and securing the landfill site after the end of its life cycle had to be planned in order to carry out these activities in accordance with the law. Necessary funds have to be available at the time of closure of the landfill. The costs of education of employees and promotional activities aimed at raising public awareness are set at $€ 50,000$.

An overview of total projected operating costs of the landfill is given in Table 2.

Table 2. Projection of total operating costs (in EUR)

\begin{tabular}{|l|c|c|c|c|c|c|c|}
\hline \multirow{2}{*}{ Types of costs } & \multicolumn{7}{|c|}{ Year } \\
\cline { 2 - 8 } & $\mathbf{2 0 1 7}$ & $\mathbf{2 0 2 1}$ & $\mathbf{2 0 2 6}$ & $\mathbf{2 0 3 1}$ & $\mathbf{2 0 3 6}$ & $\mathbf{2 0 4 1}$ & $\mathbf{2 0 4 5}$ \\
\hline Workforce costs & 287.640 & 323.741 & 375.305 & 435.081 & 504.378 & 584.713 & 658.100 \\
\hline Administrative costs & 28.764 & 32.374 & 37.530 & 43.508 & 50.438 & 58.471 & 65.810 \\
\hline Fuel & 100.589 & 113.214 & 131.246 & 152.150 & 176.383 & 204.477 & 230.140 \\
\hline Electricity & 183.014 & 227.367 & 298.218 & 391.146 & 513.032 & 672.898 & 835.976 \\
\hline Water & 796 & 896 & 1.039 & 1.204 & 1.396 & 1.618 & 1.821 \\
\hline Chemicals & 21.000 & 23.636 & 27.400 & 31.764 & 36.824 & 42.689 & 48.046 \\
\hline Monitoring & 60.000 & 67.531 & 78.286 & 90.755 & 105.210 & 121.968 & 137.276 \\
\hline Maintenance & 154.697 & 174.113 & 201.844 & 233.993 & 271.262 & 314.467 & 353.936 \\
\hline Rehabilitation & 450.000 & 506.479 & 587.148 & 680.665 & 789.078 & 914.757 & 1.029 .567 \\
\hline Insurance & 102.000 & 114.802 & 133.087 & 154.284 & 178.858 & 207.345 & 233.369 \\
\hline Education and marketing & 50.000 & 56.275 & 65.239 & 75.629 & 87.675 & 101.640 & 114.396 \\
\hline Total costs & 1.438 .500 & 1.640 .428 & 1.936 .342 & 2.290 .181 & 2.714 .534 & 3.225 .043 & 3.708 .437 \\
\hline
\end{tabular}


In addition to the estimate of economic costs, an estimate of the following economic benefits of the project was also derived: revenue realized by charging fee for management and disposal of waste, remaining/residual value of the project, and ecological benefits.

The fee for waste management and disposal that local governments pay to the regional company for the disposal of waste into the landfill is projected at the level of the minimum price of services. It only ensures the landfill sustainability and does not exceed the assumed maximum socially acceptable price of $1 €$ per month per capita. The fees/tariffs for a full coverage of costs are presented in Table 3 taking into account the total investment and operating costs of the landfill.

Table 3. Fees/tariffs calculation for full coverage of costs (in EUR)

\begin{tabular}{|r|l|}
\hline Total investment costs [EUR] & 8.686 .538 \\
\hline Total operating costs [EUR] & 69.319 .941 \\
\hline Total cover costs [EUR] & 78.006 .479 \\
\hline Collected waste [t] & 3.595 .001 \\
\hline Total coverage tariff [per ton] & 21.70 \\
\hline Total coverage tariff [per $\mathrm{m}^{3}$ ] & 17.36 \\
\hline
\end{tabular}

Projected revenues from waste management and waste disposal are shown in Table 4.

The remaining/residual value of the project is almost annulled at the end of the project life due to nature of this type of project. Ecological benefits arising from abatement of environmental pollution can be assessed in many ways including a comparison of the existing and future emissions charges. The authors of this paper propose that the most suitable approach in this case is the application of potential valuation studies. Ideally, such project would have to contain an evaluation study prepared in order to assess "willingness to pay" of the population concerned. However, in many cases, such studies are not practical and an alternative source of estimation is almost always needed. Ecological benefits of the project associated with the project completion in this sector are determined in accordance with the current EU methodology [31] whose consistent application requires estimate of the benefits of full compliance with the EU standards in the field of living environment.

This analysis included a macroeconomic estimate of external factors values taken from the report of the European Commission (EC), which provides calculations of external benefits of adequate waste disposal as a result of conducted researches [33]. In this analysis, external benefits were calculated in the same manner, in order to obtain a rough estimate for the region concerned, in proportion to the analysed countries in transition. In this regard, the following conclusions can be reached:

a) the population included in the analysis of the EC report is 170.1 million,

b) the estimated annual benefits in case of application of the solid waste directives amount to EUR 45 per capita.

However, the estimate of the authors was that in this regard certain changes need to be introduced and integrated based on the following assumptions:

- $100 \%$ benefits will not be achieved prior to 2022 , which is a minimum of 6 years after the opening of the regional landfill;

- Value of the landfill benefits can be estimated at $30 \%$ of the total gains from the modern integrated system for disposal of solid waste, which is fully in line with the EU regulations. This benefit value includes the price and income increase until 2016.

Their application to the region in which the project is implemented is estimated as a relevant proportion of population in accordance with the implementation dynamics, which is taken for this rough estimate to be $10 \%$ in 2016 and $100 \%$ in 2022 . Based on the above assumed circumstances and elements, ecological benefits of the landfill have been projected as shown in Table 5.

\subsection{Analysis results}

Specific assumptions introduced in the analysis are presented in the following part of the paper. Final results of the financial and socio-economic feasibility analysis - financial and economic impact of the project - are also shown.

Table 4. Projection of revenues from waste management fees (in EUR)

\begin{tabular}{|l|c|c|c|c|c|c|c|}
\hline \multirow{2}{*}{ Revenues } & \multicolumn{4}{|c|}{ Year } \\
\cline { 2 - 7 } & $\mathbf{2 0 1 7}$ & $\mathbf{2 0 2 1}$ & $\mathbf{2 0 2 6}$ & $\mathbf{2 0 3 1}$ & $\mathbf{2 0 3 6}$ & $\mathbf{2 0 4 1}$ & $\mathbf{2 0 4 5}$ \\
\hline Collected waste [t] & 116.974 & 122.999 & 122.692 & 122.227 & 125.115 & 128.979 & 132.408 \\
\hline Total revenues [EUR] & 2.465 .256 & 2.592 .234 & 2.585 .764 & 2.575 .964 & 2.636 .829 & 2.718 .254 & 2.790 .541 \\
\hline
\end{tabular}

Table 5. Projection of ecological benefits (in EUR)

\begin{tabular}{|l|c|c|c|c|c|c|c|}
\hline \multicolumn{1}{|c|}{ Year } & $\mathbf{2 0 1 7}$ & $\mathbf{2 0 2 1}$ & $\mathbf{2 0 2 6}$ & $\mathbf{2 0 3 1}$ & $\mathbf{2 0 3 6}$ & $\mathbf{2 0 4 1}$ & $\mathbf{2 0 4 5}$ \\
\hline Population & 354.326 & 350.968 & 349.929 & 351.355 & 355.545 & 362.786 & 364.239 \\
\hline Revenues [EUR] & 478.340 & 2.842 .841 & 4.724 .042 & 4.743 .293 & 4.799 .858 & 4.897 .611 & 4.917 .231 \\
\hline
\end{tabular}




\subsubsection{Financial impact of the project}

In order to fully understand the analysis, the following must be noted:

- Analysis is carried out in euros

- Analysis is performed using real (constant) prices

- Analysis is "incremental", as it involves comparison between the situation in which the project would be implemented ("scenario with the project") and the current situation ("scenario without the project").

In order to conduct a financial analysis, the following assumptions are introduced:

- Discount rate is 7,5\%: In accordance with the options offered in the EC Guide to Cost-Benefit Analysis of investment projects [31], in order to assess a reasonable discount rate which should represent the financial situation in developing countries, taking into account the movement of interest on the borrowed funds, the authors of this paper consider that the financial discount rate of $7.5 \%$ represents a real cost and risk of lending money in developing countries at the assumed point in time of this analysis - 2014. We emphasize that the EC agrees with the fact that discount rates can vary with respect to the rates proposed in the EC Regulation (No. 480/2014) for the programming period 2014-2020 due to the impact of "international macroeconomic trends and conjunctures, specific macroeconomic conditions in the member state, and the nature of the investor and sector" [31].

- Increase of medium-term economic growth rates of $1 \%$ of GDP in 2014 and $1 \%$ for 2015 and 2016.

- Actual/real wage growth - will correspond to the GDP growth rate.

The FNPV and FIRR determination is based on the discount free cash flows/operating surpluses from the regional landfill

Table 6. Projection of net effect balance trends in financial analysis (in EUR)

\begin{tabular}{|l|c|c|c|c|c|c|c|}
\hline \multicolumn{1}{|c|}{ Year } & $\mathbf{2 0 1 4}$ & $\mathbf{2 0 1 5}$ & $\mathbf{2 0 1 6}$ & $\mathbf{2 0 1 7}$ & $\mathbf{2 0 1 8}$ & $\mathbf{2 0 1 9}$ & $\mathbf{2 0 2 0}$ \\
\hline Fees revenues & 0 & 0 & 0 & 1.483 .500 & 1.486 .367 & 1.535 .934 & 1.587 .264 \\
\hline Total revenue & 0 & 0 & 0 & 1.483 .500 & 1.486 .367 & 1.535 .934 & 1.587 .264 \\
\hline Investments & 0 & 4.343 .269 & 4.343 .269 & 0 & 0 & 0 & 0 \\
\hline Operating costs & 0 & 0 & 0 & 1.483 .500 & 1.486 .367 & 1.535 .934 & 1.587 .264 \\
\hline Total costs & 0 & 4.343 .269 & 4.343 .269 & 1.483 .500 & 1.486 .367 & 1.535 .934 & 1.587 .264 \\
\hline Net financial effects & 0 & -4.343 .269 & -4.343 .269 & 0 & 0 & 0 & 0 \\
\hline
\end{tabular}

\begin{tabular}{|c|c|c|c|c|c|c|c|c|c|c|c|}
\hline 2021 & \multicolumn{2}{|l|}{2022} & 2023 & \multicolumn{2}{|c|}{2024} & \multicolumn{2}{|c|}{2025} & \multicolumn{2}{|r|}{2026} & 2027 & 2028 \\
\hline 1.640 .428 & \multicolumn{2}{|c|}{1.695 .495} & 1.752 .541 & \multicolumn{2}{|c|}{1.811 .643} & \multicolumn{2}{|c|}{1.872 .882} & \multicolumn{2}{|c|}{1.936 .342} & 2.002 .111 & 2.070 .282 \\
\hline 1.640 .428 & \multicolumn{2}{|l|}{1.695 .495} & 1.752 .541 & \multicolumn{2}{|c|}{1.811 .643} & \multicolumn{2}{|c|}{1.872 .882} & \multicolumn{2}{|c|}{1.936 .342} & 2.002 .111 & 2.070 .282 \\
\hline 0 & \multicolumn{2}{|l|}{0} & 0 & \multicolumn{2}{|c|}{0} & \multicolumn{2}{|c|}{0} & \multicolumn{2}{|r|}{0} & 0 & 0 \\
\hline 1.640 .428 & \multicolumn{2}{|c|}{1.695 .495} & 1.752 .541 & \multicolumn{2}{|c|}{1.811 .643} & \multicolumn{2}{|c|}{1.872 .882} & \multicolumn{2}{|c|}{1.936 .342} & 2.002 .111 & 2.070 .282 \\
\hline 1.640 .428 & \multicolumn{2}{|l|}{1.695 .495} & 1.752 .541 & \multicolumn{2}{|c|}{1.811 .643} & \multicolumn{2}{|c|}{1.872 .882} & \multicolumn{2}{|c|}{1.936 .342} & 2.002 .111 & 2.070 .282 \\
\hline 0 & \multicolumn{2}{|l|}{0} & 0 & \multicolumn{2}{|c|}{0} & & 0 & & 0 & 0 & 0 \\
\hline 2029 & 2030 & & 2031 & & & & 333 & & 2034 & 2035 & 2036 \\
\hline 2.140 .950 & 2.214 .214 & & 2.290 .181 & 2.36 & & & 0.661 & & .535 .407 & 2.623 .321 & 2.714 .534 \\
\hline 2.140 .950 & 2.214 .214 & & 2.290 .181 & 2.36 & & & 0.661 & & .535 .407 & 2.623 .321 & 2.714 .534 \\
\hline 0 & 0 & & 0 & & & & 0 & & 0 & 0 & 0 \\
\hline 2.140 .950 & 2.214 .214 & & 2.290 .181 & 2.36 & & & 0.661 & & .535 .407 & 2.623 .321 & 2.714 .534 \\
\hline 2.140 .950 & 2.214 .214 & & 2.290 .181 & 2.36 & & & 0.661 & & .535 .407 & 2.623.321 & 2.714 .534 \\
\hline 0 & 0 & & 0 & & & & 0 & & 0 & 0 & 0 \\
\hline 2037 & 2038 & & 2039 & 2040 & & & 20 & & 2043 & 2044 & 2045 \\
\hline 2.809 .180 & 2.907 .403 & & .009 .350 & 3.115 .176 & & & 3.33 & & 3.457 .588 & 3.580 .629 & 3.708 .437 \\
\hline 2.809 .180 & 2.907 .403 & & 009.350 & 3.115 .176 & & 043 & 3.33 & & 3.457 .588 & 3.580 .629 & 3.708 .437 \\
\hline 0 & 0 & 0 & & 0 & & & ( & & 0 & 0 & 0 \\
\hline 2.809 .180 & 2.907 .403 & & .009 .350 & 3.115 .176 & & & 3.33 & & 3.457 .588 & 3.580 .629 & 3.708 .437 \\
\hline 2.809 .180 & 2.907 .403 & & 009.350 & 3.115 .176 & & & 3.33 & & 3.457 .588 & 3.580 .629 & 3.708 .437 \\
\hline 0 & 0 & 0 & & 0 & & & ( & & 0 & 0 & 0 \\
\hline
\end{tabular}


operation. Since the financial analysis is conducted according to the model of incremental cash flows, incremental cash flows presented in Table 6 represent the basis for calculating the FNPV for the project. Inflows include revenue increase resulting from the projected increase in the amount of waste that comes directly to the landfill. The changes in investment and operating costs of the project implementation are taken into account in the forecast of project costs.

Based on the final results of the financial analysis (Table 7), the following conclusions can be made:

- FNPV of the project calculated at the discount rate of $7.5 \%$ for an operational period of 30 years has a negative value, which means that the project does not achieve an adequate return and is financially not profitable;
Table 7. Final financial analysis results

\begin{tabular}{|c|c|}
\hline Discount rate & $7,5 \%$ \\
\hline FNPV [EUR] & -7.798 .622 \\
\hline FIRR & - \\
\hline B/C & 0,84 \\
\hline
\end{tabular}

\section{Table 8. Conversion factor (CF)}

\begin{tabular}{|l|l|}
\hline Conversion factor for construction costs & 0.8231 \\
\hline Conversion factor for earnings & 0.5852 \\
\hline Conversion factor for equipment & 0.8595 \\
\hline
\end{tabular}

Table 9. Projection of balance of net effects in socio-economic analysis (in EUR)

\begin{tabular}{|l|c|c|c|c|c|c|c|}
\hline \multicolumn{1}{|c|}{ Year } & $\mathbf{2 0 1 4}$ & $\mathbf{2 0 1 5}$ & $\mathbf{2 0 1 6}$ & $\mathbf{2 0 1 7}$ & $\mathbf{2 0 1 8}$ & $\mathbf{2 0 1 9}$ & $\mathbf{2 0 2 0}$ \\
\hline Economic benefits & 0 & 0 & 0 & 478.340 & 953,986 & 1.427 .346 & 1.898 .899 \\
\hline Fees revenues & 0 & 0 & 0 & 1.438 .500 & 1.486 .367 & 1.535 .934 & 1.587 .264 \\
\hline Total revenues & 0 & 0 & 0 & 1.916 .840 & 2.440 .353 & 2.963 .279 & 3.486 .163 \\
\hline Operating costs & 0 & 0 & 0 & 1.323 .858 & 1.368 .146 & 1.414 .018 & 1.461 .535 \\
\hline Investments & 0 & 3.680 .051 & 3.680 .051 & 0 & 0 & 0 & 0 \\
\hline Total costs & 0 & 3.680 .051 & 3.680 .051 & 1.323 .858 & 1.368 .146 & 1.414 .018 & 1.461 .535 \\
\hline Net economic effects & 0 & -3.680 .051 & -3.680 .051 & 592.282 & 1.072 .207 & 1.549 .261 & 2.024 .628 \\
\hline
\end{tabular}

\begin{tabular}{|c|c|c|c|c|c|c|c|}
\hline $\mathbf{2 0 2 1}$ & $\mathbf{2 0 2 2}$ & $\mathbf{2 0 2 3}$ & $\mathbf{2 0 2 4}$ & $\mathbf{2 0 2 5}$ & $\mathbf{2 0 2 6}$ & $\mathbf{2 0 2 7}$ & $\mathbf{2 0 2 8}$ \\
\hline 2.842 .841 & 3.786 .167 & 4.728 .753 & 4.726 .053 & 4.724 .555 & 4.724 .042 & 4.725 .149 & 4.727 .646 \\
\hline 1.640 .428 & 1.695 .495 & 1.752 .541 & 1.811 .643 & 1.872 .882 & 1.936 .342 & 2.002 .111 & 2.070 .282 \\
\hline 4.483 .269 & 5.481 .662 & 6.481 .294 & 6.537 .696 & 6.597 .436 & 6.660 .383 & 6.727 .260 & 6.797 .928 \\
\hline 1.510 .762 & 1.561 .766 & 1.614 .616 & 1.669 .387 & 1.726 .153 & 1.784 .995 & 1.845 .996 & 1.909 .243 \\
\hline 0 & 0 & 0 & 0 & 0 & 0 & 0 & 0 \\
\hline 1.510 .762 & 1.561 .766 & 1.614 .616 & 1.669 .387 & 1.726 .153 & 1.784 .995 & 1.845 .996 & 1.909 .243 \\
\hline 2.972 .506 & 3.919 .896 & 4.866 .678 & 4.868 .309 & 4.871 .283 & 4.875 .388 & 4.881 .263 & 4.888 .685 \\
\hline
\end{tabular}

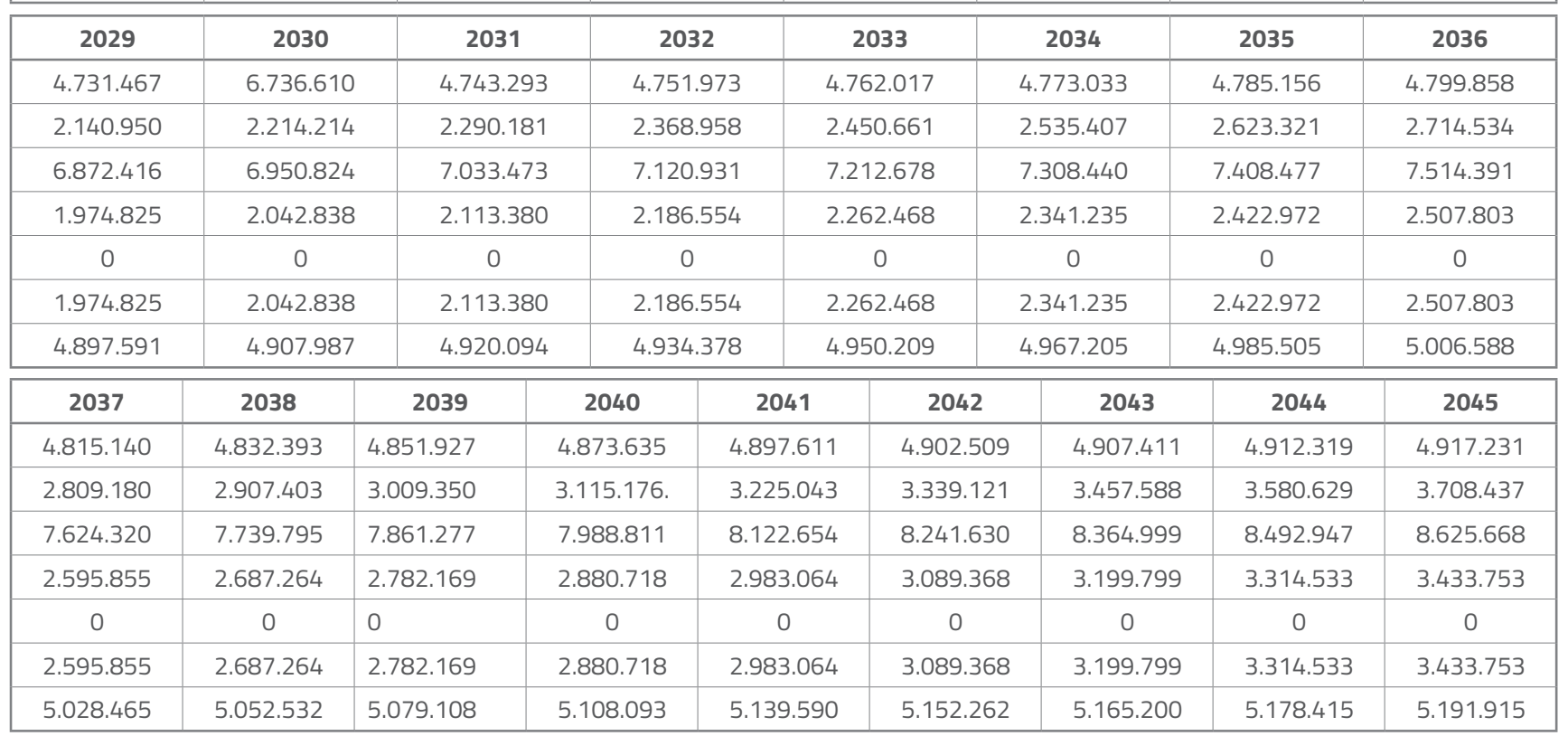


- FIRR could not be determined by calculation, considering that the project is financially unsustainable. In the net effect balance projection, apart to the negative value of investment in the early years, there is no positive net effect whose discounting could enable determination of the FIRR;

- $B / C$ ratio is less than 1 , which further confirms financial unsustainability of the project.

Negative FNPV and FIRR values are one of the two conditions for the project to be eligible for EU co-financing [31]. The second condition has to be confirmed through a socio-economic analysis of project justification.

\subsubsection{Socio-economic impact of the project}

In order to implement the socio-economic feasibility analysis of the project, an assumption that the economic discount rate is $8.5 \%$ has been introduced. This, according to the authors, reflects the opportunity cost of investing money in developing countries at the predicted point in time of the analysis - 2014 .

During the analysis, all required steps envisaged for the implementation of socio-economic analysis of the project have been met, as follows:

- Conversion of market prices into billing prices

- Monetization of non-market impacts

- Inclusion of additional indirect impacts

- Discounting the estimated costs and benefits

- Calculation of key indicators of socio-economic impact of the project (ENPV, EIRR, and B/C).

All prices covered by the analysis are adjusted to "economic values" without direct and indirect taxes, social security costs, and other externalities (because they are not real economic costs nor benefits for society as a whole). In this respect, the following rules have been established in order to adjust cash flows from financial analysis for economic analysis:

- Input and output prices should be reduced by the value added tax (VAT). Consumers pay the tax included in the price of the product (transfer from consumers to the project), these funds are transferred to the state (transfer from the project to the country) and used for realization of projects of public interest (transfer from the state to consumers) and

- Input prices should be reduced by the direct and indirect taxes.
If the exact value of transfer payments can be determined, it should be directly excluded using conversion factors. For calculation of the project economic values using the conversion factor (CF), the following assumptions have been adopted (Table 8):

After the aforementioned corrections and harmonisations of net cash flow balances due to economic costs and the benefits of the project, the net economic effects of the project are determined. The projection of the balance of net effects in the socio-economic analysis is shown in Table 9. Based on these effects, the key indicators of socio-economic feasibility of the project have been calculated.

Based on the final results of the socio-economic analysis (Table $10)$, it can be concluded that:

- ENPV of the project defined at the discount rate of $8.5 \%$ for an operational period of 30 years is positive;

- EIRR is $27,87 \%$ (it is higher than the discount rate defined for the project);

- $B / C$ is higher than 1.

Table 10. Final socio-economic analysis results

\begin{tabular}{|c|c|}
\hline Discount rate [\%] & 8,5 \\
\hline ENPV [EUR] & 26.354 .085 \\
\hline EIRR [\%] & 27,87 \\
\hline B/C & 2,52 \\
\hline
\end{tabular}

The final results of the analysis i.e. all key indicators point to the socio-economic feasibility of the investment suggesting that the project should be implemented.

\subsection{Analysis of project sensitivity to investment risks}

The project sensitivity analysis was conducted after proper evaluation of all relevant financial and socio-economic effects of the investment. This analysis was made to determine whether and to what extent the profitability of the project changes in case of variation of some key input parameters.

The results of the project sensitivity analysis with the corresponding IRR and NPV values are presented in Tables 11 and 12 , separately for financial and socio-economic analyses of the project.

The project resistance to the change of all forms of real input parameters in the socio-economic analysis was proven based on sensitivity testing. This confirmed the socio-economic

Table 11. Results of sensitivity analysis for financial analysis

\begin{tabular}{|c|c|c|c|}
\hline Test type & Input parameters change & FIRR & FNPV [EUR] \\
\hline Basic situation & - & - & -7.798 .622 \\
\hline Increase in investment and maintenance costs & $+20 \%$ & - & -9.379 .893 \\
\hline Decrease in investment and maintenance costs & $-20 \%$ & - & -6.253 .262 \\
\hline Increase in revenues from services & $+20 \%$ & - & -3.850 .810 \\
\hline Decrease in revenues from services & $-20 \%$ & - & -11.782 .344 \\
\hline
\end{tabular}


Table 12. Results of sensitivity analysis for socio-economic analysis

\begin{tabular}{|c|c|c|c|}
\hline Test type & Input parameters change & EIRR & ENPV [EUR] \\
\hline Basic situation & - & $27,87 \%$ & 26.354 .085 \\
\hline Increase in investment and maintenance costs & $+20 \%$ & $24,87 \%$ & 25.014 .657 \\
\hline Decrease in investment and maintenance costs & $-20 \%$ & $31,77 \%$ & 27.627 .777 \\
\hline Increase in revenues from services & $+20 \%$ & $29,90 \%$ & 29.526 .503 \\
\hline Decrease in revenues from services & $-20 \%$ & $25,72 \%$ & 23.115 .931 \\
\hline
\end{tabular}

feasibility of the project. However, the project did not show resistance to assumed change of input parameters in the context of financial analysis, which was expected.

\section{Conclusion}

The results of the financial and socio-economic analysis of feasibility of a hypothetical project involving construction of a regional landfill for municipal (non-hazardous) waste undoubtedly confirmed both hypotheses defined for this study. The analysis showed the following:

- The need for comprehensive assessment of justification/ feasibility of some investments is imposed by the lack of market-based valorisation of significant effects of some projects on the overall development of the community and on the wellbeing of local population. Assessment of the socioeconomic perspective of the project has a higher specific weight compared to the traditional financial sustainability of the project. Both developed and developing countries should take this into account. This especially applies to public-sector projects in developing countries due to lower interest of the private sector for known reasons;
- As on some projects developing countries need to determine prices that are acceptable from the socio-economic aspect (and are generally lower than commercial prices), financial sustainability of such projects is usually inadequate, and so these projects have to be justified based on relevant socio-economic benefits and net contributions to the overall development of community and its life.

Investments in waste sector generally show similar results. The results obtained in the framework of financial analysis conducted for this project are typical for projects in which the related costs (capital and operational costs) are incurred, but revenues do not increase to an appropriate/significant extent. Poor FNPV and FIRR values indicate that such projects should be co-financed (by international financial institutions, funds etc.), especially as they are not likely to attract private funding (because of pricing, special pricing policies, etc.). However, in these and similar projects, socioeconomic benefits are often given preference over net financial benefits, i.e. the financial analysis can not serve as the sole basis for deciding on whether the project should be implemented.

\section{REFERENCES}

[1] Bennett, F.L.: The management of construction: a project life cycle approach, Butterworth-Heinemann, 2003.

[2] Fabozzi, F.J., Peterson, P. P.: Financial management and analysis, Second edition, Hoboken, NJ: John Wiley \& Sons, 2003.

[3] Gitman, L.J., Madura, J.: Introduction to Finance, Pearson, 2001.

[4] Graham, J.R., Harvey, C.R.: The theory and practice of corporate finance: evidence from the field, Journal of Financial Economics, 60 (2001), pp. 187-243, https://doi.org/10.1016/50304405X(01)00044-7

[5] Danielson, M.G., Scott, J.A.: The Capital Budgeting Decisions of Small Businesses, Journal of Applied Finance, 16 (2006) 2, pp. 45.

[6] Gitman, L.J., Forrester, J.R.: A survey of capital-budgeting techniques used by major U.S. tvrtks. Financial Management, 6 (1977) 3, pp. 66-71.

[7] Stanley, M.T., Block, S.B.: A survey of multinational capital budgeting, The Financial Review, 19 (1984), pp. 36-54, https://doi. org/10.1111/j.1540-6288.1984.tb01083.x
[8] Moore, J.S., Reichert, A.K.: An analysis of the financial management techniques currently employed by large. U.S. corporations, Journal of Business Finance and Accounting, 10 (1983), pp. 623-645, https://doi.org/10.1111/j.1468-5957.1983.tb00456.x

[9] Bierman, H.J.: Capital budgeting in 1992: a survey, Financial Management, 22 (1993), pp. 24, https://doi.org/10.2307/3665921

[10] Trahan, E.A., Gitman, L.J.: Bridging the theory-practice gap in corporate finance: a survey of chief financial officers, Quarterly Review of Economics and Finance, 35 (1995), pp. 73-87, https:// doi.org/10.1016/1062-9769(95)90063-2

[11] Chen, X.: A Systematic Comparison of Municipal Solid Waste Management Systems: Case Studies of Dalian City, China and the Region of Waterloo, Canada, University of Waterloo, Ontario, Canada, 2008

[12] Louis, G.E.: A Historical Context of Municipal Solid Waste Management in the United States, Waste Management \& Research, 22 (2004) 4, pp. 306-22. 
[13] Hostovsky, C.: Integrating Planning Theory and Waste Management: An Annotated Bibliography, Journal of Planning Literature, 15 (2000) 2, pp. 305-32.

[14] Goddard, H.C.: The Benefits and Costs of Alternative Solid Waste Management Policies, Resources, Conservation and Recycling, 13 (1995), pp. 183-213, https://doi.org/10.1016/09213449(94)00021-V

[15] Zavodska, A.: A Comparative Study on Residential Solid Waste Management in Selected Developing and Developed Countries: Guyana and United States, The University of Arizona, 2000.

[16] Dai, H., Dai, P.: Integrated Waste Management (IWM) Should Be Implemented for Municipal Waste Management, Journal of Chongqing Technology Business University (Natural Science Edition), 21 (2004), 2, pp. 105-110.

[17] Hoornweg, D., Lam, P., Chaudry, M.: What a Waste: Solid Waste Management in China: Issues and Recommendations, Urban Development Sector Unit, East Asia Infrastructure Department: World Bank, Washingtonm DC, Working papers no. 9, 2005.

[18] Seadon, J.K.: Integrated Waste Management - Looking Beyond the Solid Waste Horizon, Waste Management, 26 (2006) 12, pp. 1327-1336.

[19] Parthan, S.R., Milke, M.W., Wilson, D.C., Cocks, J.H.: Cost estimation for solid waste management in industrialising regions - Precedents, problems and prospects, Waste Management, 32 (2012), pp. 584-594, https://doi.org/10.1016/j.wasman.2011.11.004

[20] Milke, M.: The Alchemist's dream resource, Waste Management, 26 (2006), pp. 1203-1204, https://doi.org/10.1016/j. wasman.2006.08.001

[21] Diaz, L., Savage, G., Eggerth, L., Golueke, C.: Solid Waste Management for Economically Developing Countries, ISWA Copenhagen: Denmark, 1996.

[22] Bartone, C., Bernstein, J., Wright, F.: Investments in Solid Waste Management. Infrastructure and Urban Development Department, Opportunities for Environmental Improvement, World Bank, Urban Development Division, Infrastructure and Urban Development Department, 1990.
[23] Clark, R., Grupenhoff, B., Garland, G.: Cost of residential solid waste collection, Journal of the Sanitary Engineering Division, 97 (1971), pp. 563-568.

[24] Chang, N., Wang, S.: A fuzzy goal programming approach for the optimal planning of metropolitan solid waste management systems, Euraopean Journal of Operational Research, 99 (1997), pp. 303-321, https://doi.org/10.1016/S0377-2217(96)00024-0

[25] Huang, G.H., Sae-Lim, N., Liu, L., Chen, Z.: An interval-parameter fuzzy-stochastic programming approach for municipal solid waste management and planning, Environmental Modeling and Assessment, 6 (2001), pp. 271-283, https://doi. org/10.1023/A:1013394118863

[26] Palmer, K., Walls, M.: Optimal policies for solid waste disposal taxes, subsidies, and standards. Journal of Public Economics, 65 (1997), pp. 193-205, https://doi.org/10.1016/S00472727(97)00028-5

[27] Strathman, J., Rufolo, A., Mildner, G.: The demand for solid waste disposal, Land Economics, 71 (1995), pp. 57-64, https://doi. org/10.2307/3146758

[28] Jenkins, R.R.: Municipal demand for solid-waste-disposal services: the impact of user fees, College Park, MD (USA): University of Maryland, 1991.

[29] McDavid, J.: The Canadian experience with privatizing residential solid waste collection services, Public Administration Review, 45 (1985), pp. 602-608, https://doi.org/10.2307/3109936

[30] Scheinberg, A.: Wilson, D.C., Rodic L.: Solid waste management in the world's cities, water and sanitation in the world's cities, Earthscan: UN-Habitat, 2010.

[31] Guide to Cost-Benefit Analysis of Investment Projects, Economic appraisal tool for Cohesion Policy 2014-2020, Euraopean Commission, 2014

[32] Matson, J.: A cooperative feasibility study guide, U.S. Department of Agriculture, RBS Report, 58 (2010)

[33] The benefits of compliance with the environmental acquis for the candidate countries, ECOTEC Research and Consulting Limited, 2001 